\title{
Atmospheric Pollution and Thyroid Function of Pregnant Women in Athens, Greece: A Pilot Study
}

\author{
Ioannis Ilias *(D), Ioannis Kakoulidis, Stefanos Togias, Stefanos Stergiotis, Aikaterini Michou, \\ Anastasia Lekkou, Vasiliki Mastrodimou, Athina Pappa, Evangelia Venaki and Eftychia Koukkou \\ Department of Endocrinology, Diabetes and Metabolism, Elena Venizelou Hospital, 11521 Athens, Greece; \\ i_kakoulidis@yahoo.gr (I.K.); s.tog90@gmail.com (S.T.); stef_ster@hotmail.com (S.S.); \\ katerina.michoy@yahoo.com (A.M.); anastasia.lk@gmail.com (A.L.); si-li-a@hotmail.com (V.M.); \\ athpappa@gmail.com (A.P.); e_venaki@gmail.com (E.V.); ekoukkou@gmail.com (E.K.) \\ * Correspondence: iiliasmd@yahoo.com
}

Received: 23 January 2020; Accepted: 1 April 2020; Published: 4 April 2020

\begin{abstract}
Exposure to air pollution and, in particular, to nitrogen dioxide $\left(\mathrm{NO}_{2}\right)$ or particulate pollutants less than $2.5 \mu \mathrm{m}$ (PM2.5) or $10 \mu \mathrm{m}$ (PM10) in diameter has been linked to thyroid (dys)function in pregnant women. We hypothesized that there may be a dose-effect relationship between air pollutants and thyroid function parameters. We retrospectively evaluated thyrotropin (TSH) in 293 women, $\mathrm{NO}_{2}$, PM2.5 and PM10 levels in Athens. All the women were diagnosed with hypothyroidism for the first time during their pregnancy. Exposure to air pollution for each woman was considered according to her place of residence. Statistical analysis of age, pregnancy weight change, and air pollutants versus TSH was performed with ordinary least squares regression (OLS-R) and quantile regression (Q-R). A positive correlation for logTSH and PM2.5 $(r=+0.13, p=0.02)$ was found, using OLS-R. Further analysis with Q-R showed that each incremental unit increase (for the 10th to the 90th response quantile) in PM2.5 increased $\log \mathrm{TSH}( \pm \mathrm{SE})$ between $+0.029(0.001)$ to +0.025 $(0.001) \mathrm{mIU} / \mathrm{L}(p<0.01)$. The other parameters and pollutants $\left(\mathrm{PM} 10\right.$ and $\left.\mathrm{NO}_{2}\right)$ had no significant effect on TSH. Our results indeed show a dose-response relationship between PM2.5 and TSH. The mechanisms involved in the pathophysiological effects of atmospheric pollutants, in particular PM2.5, are being investigated.
\end{abstract}

Keywords: pregnancy; thyrotropin; environmental air pollutants

\section{Introduction}

The offspring of pregnant women that have been exposed to air pollutants show structural brain alterations, reduced executive function and behavioral problems. The tentative mechanisms for these problems may be oxidative stress, neuroinflammation or changes in the hypothalamic-pituitary-adrenal axis [1]. Thyroid hormones are crucial in the development of the fetal brain. The fetal thyroid gland is fully functional after mid-pregnancy, thus undiagnosed or less than optimally treated thyroid insufficiency early on in pregnancy adversely affects the development the offspring. Studies have shown a link between pollutants (polycyclic aromatic hydrocarbons) and maternal thyroid function [1]. Particulate air pollutants are prevalent and harmful to humans (as assessed versus mortality, morbidity or cardiovascular disease) [2]; however, data on whether exposure to particulate air pollutants can also disrupt thyroid function in pregnancy are limited. Recently, exposure to ambient air pollution (and more in detail to nitrogen dioxide- $\mathrm{NO}_{2}$ or particulate air pollutants with a diameter of less than 2.5 micrometers-PM2.5 or 10 micrometers-PM10) has been linked to thyroid (dys)function in pregnant women (and/or their fetuses/neonates) [1,3-5]. The largest-scale study was based on satellite-assessed pollution measurements, whereas smaller scale studies were done with near-ground 
level air pollution assessments. These studies were honed on women living in northern Europe ( $n=6472$, the Netherlands [4]) or lower latitudes ( $n=11,927$, in China, Spain, USA or Greece [1,3,5]). Close evaluation of the reported results showed differences among Spain, USA and Greece (regarding the latter, results stemmed from a study in a provincial town and suburban/rural settings in the island of Crete). Nutritional (p.ex. regarding iodine deficiency) and environmental (p.ex. regarding type of pollutants exposed to) differences do exist among these populations [6-19]. The environmental degradation, which has occurred in recent years in urban and suburban settings in Greece [20], led us to the localized study of air pollution vs. thyroid status in pregnant women in Athens, Greece. We hypothesized that a dose-effect relationship might exist between air pollutants and thyroid parameters in pregnant women with various degrees of thyroid dysfunction.

\section{Materials and Methods}

We retrospectively evaluated thyroid function status (with thyrotropin-TSH) in 293 caucasian Greek women (mean age \pm SD: $30.9 \pm 5.9$ years) in the second or third trimester of pregnancy vs. the average preceding nine-month $\mathrm{NO}_{2}, \mathrm{PM} 2.5$ and PM10 levels from five government-run air quality measuring stations in the metropolitan Athens area [21]. In this study, we used readily available data from the subjects' medical records, history and laboratory results. The study was approved by our hospital's scientific board/ethics committee (No 18/2019)

\subsection{Study Population}

The women studied were part of a larger sample of women that were referred (post-screening) for thyroid dysfunction during pregnancy in the largest state-run maternity hospital in Greece (this hospital caters to the needs of approximately 7000 pregnant women per year in an area where approximately 32,000 women give birth annually). All the women had no prior thyroid disease and were diagnosed with hypothyroidism for the first time during their pregnancy. Characteristics of the study group are given in Table 1.

Table 1. Characteristics of the study group.

\begin{tabular}{cc}
\hline Gestational age at inclusion $($ mean \pm SD) & $19.4 \pm 8.6$ weeks \\
\hline Weight gain in pregnancy at inclusion (mean \pm SD) & $5.1 \pm 5.6 \mathrm{~kg}$ \\
\hline TSH at inclusion (mean \pm SD) & $4.54 \pm 1.66 \mathrm{mIU} / \mathrm{L}$ \\
\hline
\end{tabular}

We only included women with TSH $>2.5 \mathrm{mIU} / \mathrm{L}$ or $>3.0 \mathrm{mIU} / \mathrm{L}$ if the initial thyroid assessment was done in the first or the second trimester of pregnancy respectively.

\subsection{Exposure Measurement}

According to the Greek authorities, pollutants are measured continuously throughout the 24-h period. The response time of the automated analyzers is about one minute, that is, approximately every minute, each analyzer gives a value and average hourly pollution values are calculated. The methods used for $\mathrm{NO}_{2}$ and PM2.5/PM10 are with chemilluminescence and beta radiation attenuation, respectively. Quality control is done by the ISO-certified National Atmospheric Quality Reference Laboratory (www.ypeka.gr). Exposure to air pollutants (with nine-month mean $\pm \mathrm{SD}$ for $\mathrm{NO}_{2}, \mathrm{PM} 2.5$ and PM10 at $38.2 \pm 16.8 \mu \mathrm{g} / \mathrm{m}^{3}, 17.4 \pm 3.5 \mu \mathrm{g} / \mathrm{m}^{3}$ and $32.4 \pm 8.1 \mu \mathrm{g} / \mathrm{m}^{3}$, respectively) for each woman was considered according to her place of residence within a reasonable linear distance (up to $4-5 \mathrm{~km}$ ) from one of the five air quality measurement stations (Figures 1 and 2). 


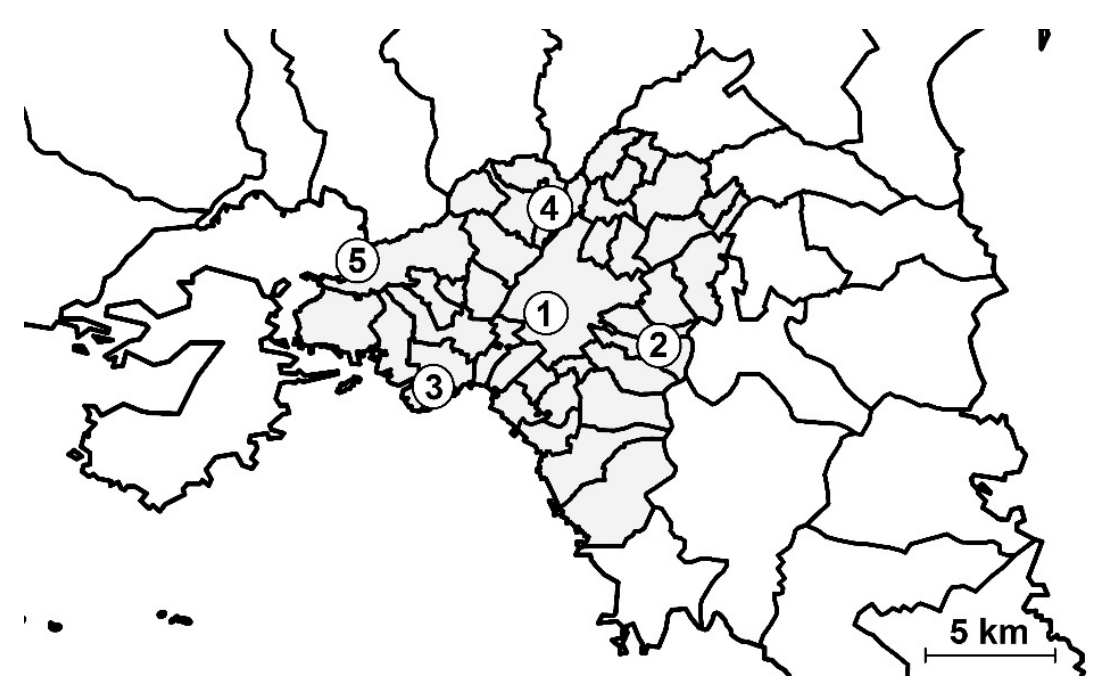

Figure 1. Air quality measurement stations in the metropolitan Athens area; 1 : central Athens (urban), 2: AgiaParaskevi (suburban), 3: Pireaus (urban), 4: Lykovrisi (suburban), 5: Eleusis/Aspropyrgos (industrial); for each woman, the nine-month average of air pollutants' levels from the closest station to her residence was taken into consideration.

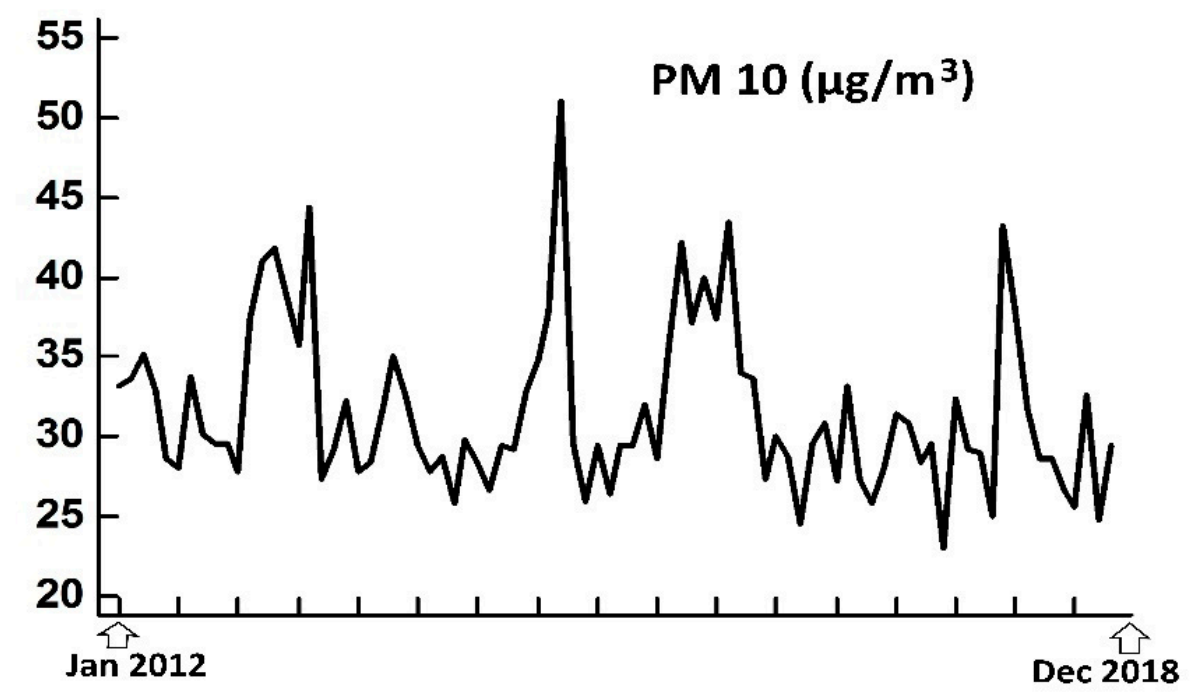

(a)

Figure 2. Cont. 


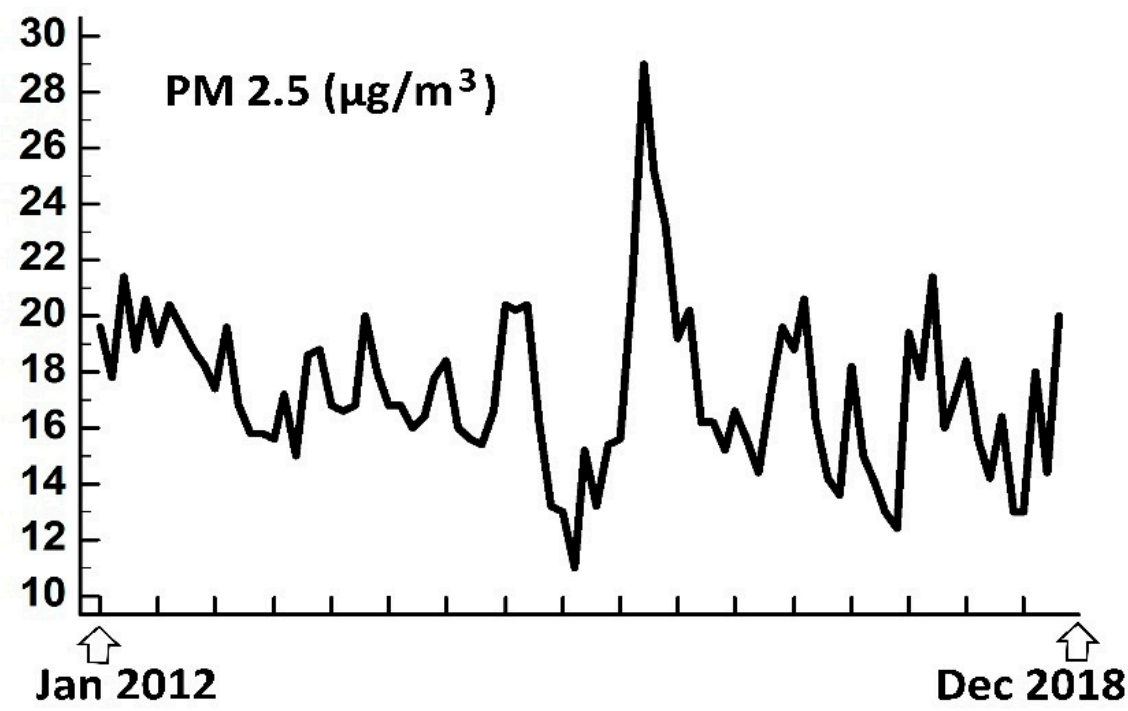

(b)

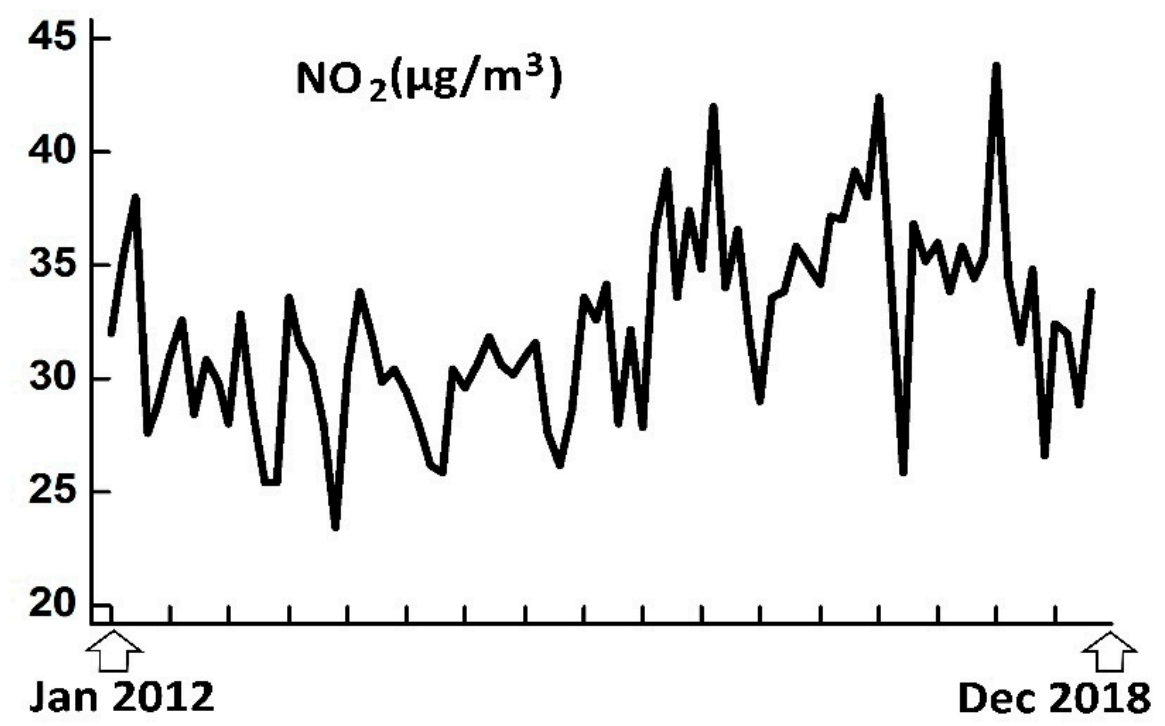

(c)

Figure 2. Average monthly air pollutants' levels PM10 (a), PM2.5 (b) and $\mathrm{NO}_{2}$ (c) from the five monitoring stations) during the study period (January 2012 to December 2018).

\subsection{Analysis}

Statistical analysis of each variable (maternal age, weight change in pregnancy and of air pollutants: PM10, PM2.5 or $\mathrm{NO}_{2}$ ) vs. TSH was done with ordinary least squares regression (OLS-R) and quantile regression [22] (OLS-R and Q-R, with Gretl, v.2019d, http://gretl.sourceforge.net/index.html). 


\section{Results}

Using OLS-R, a significant (positive) correlation for logTSH was found only with PM2.5 (with $R=+0.13, p=0.02$ ) (Figure 3a).

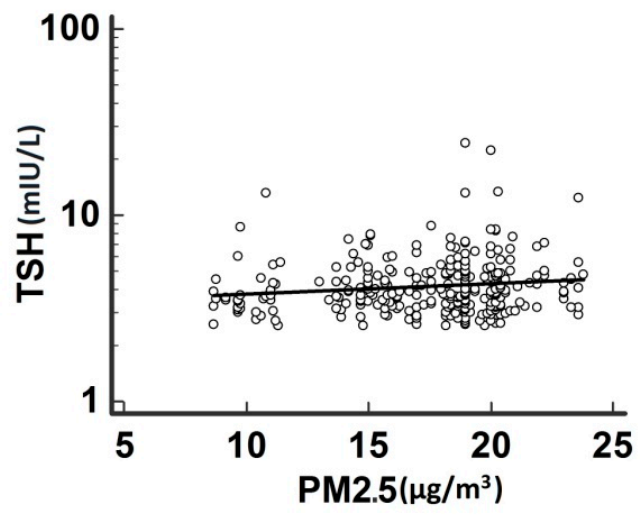

(a)

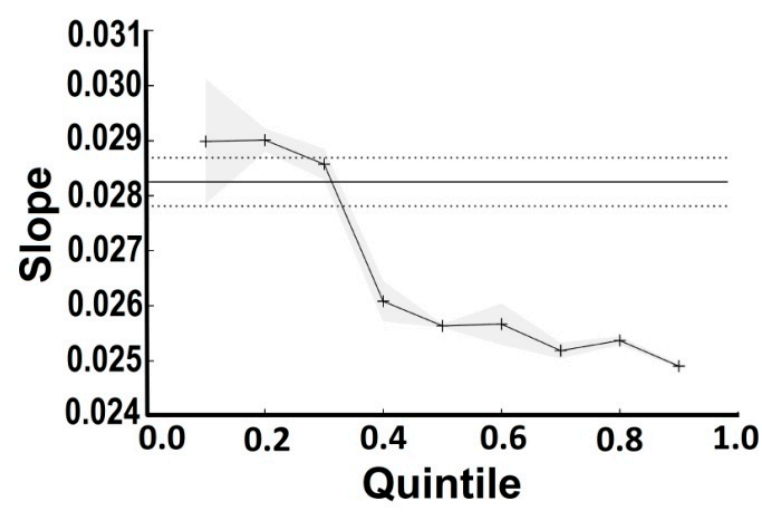

(b)

Figure 3. Scatter diagram with OLS-R for PM2.5 vs. $\log \mathrm{TSH}$ (a) Graph of slopes for PM2.5 over $\log \mathrm{TSH}(\mathrm{mIU} / \mathrm{L})$ produced by Q-R (b) Note that the 0.5 quantile corresponds to the median and that the associations between each predictor are estimated to be stronger (over the levels estimated by OLS-R) at lower quantiles of response (i.e., TSH) and weaker (lower than the levels estimated by OLS-R) at higher quintiles of response. The straight line with dashed line borders indicates the OLS-R estimate with $95 \%$ confidence intervals, whereas the splined line with grey borders indicates the Q-R estimates with $95 \%$ confidence intervals.

Further analysis with Q-R showed that each incremental unit increase in PM2.5 increased mean $\log \mathrm{TSH}( \pm$ SE) between $+0.029(0.001)$ to $+0.025(0.001) \mathrm{mIU} / \mathrm{L}$ (for the 10th to the 90th response quantile, $p<0.01$ ) (this increase is equal to a mean \pm SE increase in TSH of $1.069 \pm 1.002 \mathrm{mIU} / \mathrm{L}$ to $1.059 \pm 1.002 \mathrm{mIU} / \mathrm{L}$ ) (Figure $1 \mathrm{~b}$ ). The other parameters (maternal age, weight change in pregnancy and PM10 and $\mathrm{NO}_{2}$ levels) had no significant effect on TSH.

\section{Discussion}

Our results do indeed show a dose-response relationship between PM2.5 and maternal TSH, with a more pronounced effect on the lower TSH levels of our study sample (these levels being slightly higher than the used cut-offs) and an attenuation in the higher TSH levels. The relationship of PM2.5 to $\log$ TSH in our study was very subtle; its slope was +0.029 to +0.025 (whereas, for example, the slope of free thyroxine to $\log \mathrm{TSH}$ is reported to be approximately -0.35 [23]). The form of this association may denote a more important effect of PM2.5 at conditions of normal (or almost normal) thyroid gland status, whereas other factors may be more important at much higher TSH levels, particularly when the thyroid gland is compromised (such as in case of thyroiditis) and thyroid hormones are low. Thus, our results complement recent epidemiological works of maternal thyroid (dys)function versus PM2.5 levels [1]. The mechanisms involved in the pathophysiologic actions of ambient air pollutants-particularly of PM2.5-may be their toxicity, induction of oxidative stress and/or of inflammation and mutagenicity; all are currently under investigation [24]. Although advancing maternal age and increased body weight gain in pregnancy are associated with increase in maternal TSH [25,26], no such effects of them on TSH were noted in our sample; we can only speculate that this was the result of the sample size (additionally, regarding body weight change the range of values was also narrow).

There are caveats to be considered in this study. We used only maternal TSH and not other thyroid function/autoimmunity parameters. Although TSH is considered to be sufficient for the screening of thyroid function in pregnancy [27], the effect-if any —of pollution on any other relevant thyroid parameters was not assessed. The choice of analysing with logTSH instead of TSH values 
was guided by the relevant scientific literature, since thyroid hormones-the main determinants of TSH secretion-are linked to the latter mainly with log-linear relationships [28]. Another caveat is that we did not use satellite air pollution data-as done in other studies [1], because these cover only daytime (on cloudless days) [29-31]; the recent environmental degradation in Greece was noted to occur during nighttime in the winter due to the in-city use of open wood burning fireplaces; wood burning is a very important pollution source worldwide [32,33]. In lieu, we used "traditional"—readily available_-data from five air pollution measuring stations, a number which may be adequate for a metropolitan area of approximately of $400 \mathrm{~km}^{2}$ with $3.75 \times 10^{6}$ people [34,35]; data from a few other stations were less accessible and/or absent for the time period that was assessed. Nevertheless, there is spatial heterogeneity in ambient air pollution levels. The use of the nearest monitors' measurements to assess women's air pollution exposure may have introduced substantial exposure misclassification; we acknowledge this shortcoming of our pilot study - this is a problem to be dealt with in future studies.

Author Contributions: Conceptualization, I.I. and I.K.; Methodology, I.I. and I.K.; software, I.I.; validation, I.K., I.I and E.K.; formal analysis I.I.; investigation, I.K., I.I., S.T., S.S., A.M., A.L., V.M., A.P., E.V., E.K.; Resources, E.K.; data curation, I.I., I.K.; writing-original draft preparation, I.I. and I.K; writing-review and editing, I.I., IK. and E.K.; visualization, I.I. and I.K.; supervision, I.I. and E.K.; project administration, I.K., I.I. and E.K.; All authors have read and agreed to the published version of the manuscript.

Funding: This research received no external funding.

Conflicts of Interest: The authors declare no conflict of interest.

\section{References}

1. Ghassabian, A.; Pierotti, L.; Basterrechea, M.; Chatzi, L.; Estarlich, M.; Fernandez-Somoano, A.; Fleisch, A.F.; Gold, D.R.; Julvez, J.; Karakosta, P.; et al. Association of Exposure to Ambient Air Pollution With Thyroid Function During Pregnancy. Jama Netw Open 2019, 2, e1912902. [CrossRef] [PubMed]

2. Miller, L.; Xu, X. Ambient PM2.5 Human Health Effects-Findings in China and Research Directions. Atmosphere 2018, 9, 424. [CrossRef]

3. Wang, X.; Liu, C.; Zhang, M.; Han, Y.; Aase, H.; Villanger, G.D.; Myhre, O.; Donkelaar, A.V.; Martin, R.V.; Baines, E.A.; et al. Evaluation of Maternal Exposure to PM2.5 and Its Components on Maternal and Neonatal Thyroid Function and Birth Weight: A Cohort Study. Thyroid 2019, 29, 1147-1157. [CrossRef] [PubMed]

4. Janssen, B.G.; Saenen, N.D.; Roels, H.A.; Madhloum, N.; Gyselaers, W.; Lefebvre, W.; Penders, J.; Vanpoucke, C.; Vrijens, K.; Nawrot, T.S. Fetal Thyroid Function, Birth Weight, and in Utero Exposure to Fine Particle Air Pollution: A Birth Cohort Study. Env. Health Perspect 2017, 125, 699-705. [CrossRef] [PubMed]

5. Zhao, Y.; Cao, Z.; Li, H.; Su, X.; Yang, Y.; Liu, C.; Hua, J. Air pollution exposure in association with maternal thyroid function during early pregnancy. J. Hazard. Mater. 2019, 367, 188-193. [CrossRef]

6. Candido, A.C.; Morais, N.d.S.d.; Dutra, L.V.; Pinto, C.A.; Franceschini, S.d.C.C.; Alfenas, R.d.C.G. Insufficient iodine intake in pregnant women in different regions of the world: A systematic review. Arch. Endocrinol. Metab. 2019, 63, 306-311. [CrossRef]

7. Delshad, H.; Azizi, F. Iodine nutrition in pregnant and breastfeeding women: Sufficiency, deficiency, and supplementation. Horm. Athensgreece 2019. [CrossRef]

8. Koukkou, E.; Ilias, I.; Mamalis, I.; Adonakis, G.G.; Markou, K.B. Serum Thyroglobulin Concentration Is a Weak Marker of Iodine Status in a Pregnant Population with Iodine Deficiency. Eur. Thyroid J. 2016, 5, 120-124. [CrossRef]

9. Mills, J.L.; Ali, M.; Buck Louis, G.M.; Kannan, K.; Weck, J.; Wan, Y.; Maisog, J.; Giannakou, A.; Sundaram, R. Pregnancy Loss and Iodine Status: The LIFE Prospective Cohort Study. Nutrients 2019, 11, 534. [CrossRef]

10. Stoutjesdijk, E.; Schaafsma, A.; Dijck-Brouwer, D.A.J.; Muskiet, F.A.J. Iodine status during pregnancy and lactation: A pilot study in the Netherlands. Neth. J. Med. 2018, 76, 210-217.

11. Sun, D.; Codling, K.; Chang, S.; Zhang, S.; Shen, H.; Su, X.; Chen, Z.; Scherpbier, R.W.; Yan, J. Eliminating Iodine Deficiency in China: Achievements, Challenges and Global Implications. Nutrients 2017, 9, 361. [CrossRef] [PubMed] 
12. Torres, M.T.; Francés, L.; Vila, L.; Manresa, J.M.; Falguera, G.; Prieto, G.; Casamitjana, R.; Toran, P.; IODEGEST study group. Iodine nutritional status of women in their first trimester of pregnancy in Catalonia. BMC Pregnancy Childbirth 2017, 17, 249. [CrossRef] [PubMed]

13. Wang, Z.; Liu, P.; Su, X.; Zou, S.; Song, J.; Liu, S. A Comparison of Iodine Status in Children and Pregnant Women After a Policy Change in the Iodized Salt Standard in Shanghai, China. Biol. Trace Elem. Res. 2018, 185, 275-281. [CrossRef] [PubMed]

14. Zhao, W.; Li, X.; Xia, X.; Gao, Z.; Han, C. Iodine Nutrition During Pregnancy: Past, Present, and Future. Biol. Trace Elem. Res. 2019, 188, 196-207. [CrossRef]

15. Koukkou, E.G.; Ilias, I.; Mamalis, I.; Markou, K.B. Pregnant Greek Women May Have a Higher Prevalence of Iodine Deficiency than the General Greek Population. Eur. Thyroid J. 2017, 6, 26-30. [CrossRef]

16. Annesi-Maesano, I. The air of Europe: Where are we going? Eur. Respir. Rev. Off. J. Eur. Respir. Soc. 2017, 26, 170024. [CrossRef]

17. Fairburn, J.; Schüle, S.A.; Dreger, S.; Karla Hilz, L.; Bolte, G. Social Inequalities in Exposure to Ambient Air Pollution: A Systematic Review in the WHO European Region. Int. J. Environ. Res. Public Health 2019, 16, 3127. [CrossRef]

18. Schulz, H.; Karrasch, S.; Bölke, G.; Cyrys, J.; Hornberg, C.; Pickford, R.; Schneider, A.; Witt, C.; Hoffmann, B. Breathing: Ambient Air Pollution and Health-Part II. Pneumol. Stuttg. Ger. 2019, 73, 347-373. [CrossRef]

19. Yang, B.-Y.; Liu, Y.; Hu, L.-W.; Zeng, X.-W.; Dong, G.-H. Urgency to Assess the Health Impact of Ambient Air Pollution in China. Adv. Exp. Med. Biol. 2017, 1017, 1-6. [CrossRef]

20. Serraos, K.; Greve, T.; Asprogerakas, E.; Balampanidis, D.; Chani, A. Athens, a capital in crisis: Tracing the socio-spatial impacts. In Cities in Crisis Socio-Spatial Impacts of the Economic Crisis in Southern European Cities; Knieling, J., Othengrafen, F., Eds.; Routledge: London, UK; New York, NY, USA, 2015; pp. 116-138.

21. Air Pollution Bulletins. Available online: http://www.ypeka.gr/Default.aspx?tabid=490\&language=el-GR (accessed on 20 December 2019).

22. Hao, L.; Naiman, D.Q. Quantile Regression; Sage Publications: Thousand Oaks, CA, USA, 2007; Volume 149.

23. Rothacker, K.M.; Brown, S.J.; Hadlow, N.C.; Wardrop, R.; Walsh, J.P. Reconciling the Log-Linear and Non-Log-Linear Nature of the TSH-Free T4 Relationship: Intra-Individual Analysis of a Large Population. J. Clin. Endocrinol. Metab. 2016, 101, 1151-1158. [CrossRef]

24. Feng, S.; Gao, D.; Liao, F.; Zhou, F.; Wang, X. The health effects of ambient PM2.5 and potential mechanisms. Ecotoxicol. Environ. Saf. 2016, 128, 67-74. [CrossRef] [PubMed]

25. Collares, F.M.; Korevaar, T.I.M.; Hofman, A.; Steegers, E.A.P.; Peeters, R.P.; Jaddoe, V.W.V.; Gaillard, R. Maternal thyroid function, prepregnancy obesity and gestational weight gain-The Generation R Study: A prospective cohort study. Clin. Endocrinol. 2017, 87, 799-806. [CrossRef] [PubMed]

26. Springer, D.; Jiskra, J.; Limanova, Z.; Zima, T.; Potlukova, E. Thyroid in pregnancy: From physiology to screening. Crit. Rev. Clin. Lab. Sci. 2017, 54, 102-116. [CrossRef] [PubMed]

27. Stagnaro-Green, A.; Dong, A.; Stephenson, M.D. Universal screening for thyroid disease during pregnancy should be performed. Best Pract. Res. Clin. Endocrinol. Metab. 2019, 101320. [CrossRef] [PubMed]

28. Hoermann, R.; Midgley, J.E.M.; Larisch, R.; Dietrich, J.W. Recent Advances in Thyroid Hormone Regulation: Toward a New Paradigm for Optimal Diagnosis and Treatment. Front. Endocrinol. Lausanne 2017, 8, 364. [CrossRef] [PubMed]

29. Hoek, G. Methods for Assessing Long-Term Exposures to Outdoor Air Pollutants. Curr. Environ. Health Rep. 2017, 4, 450-462. [CrossRef] [PubMed]

30. Hoff, R.M.; Christopher, S.A. Remote sensing of particulate pollution from space: Have we reached the promised land? J. Air Waste Manag. Assoc. 1995 2009, 59, 645-675. [CrossRef]

31. Samoli, E.; Butland, B.K. Incorporating Measurement Error from Modeled Air Pollution Exposures into Epidemiological Analyses. Curr. Environ. Health Rep. 2017, 4, 472-480. [CrossRef]

32. Saffari, A.; Daher, N.; Samara, C.; Voutsa, D.; Kouras, A.; Manoli, E.; Karagkiozidou, O.; Vlachokostas, C.; Moussiopoulos, N.; Shafer, M.M.; et al. Increased biomass burning due to the economic crisis in Greece and its adverse impact on wintertime air quality in Thessaloniki. Environ. Sci. Technol. 2013, 47, 13313-13320. [CrossRef]

33. Robinson, D.L. Wood burning stoves produce PM2.5 particles in amounts similar to traffic and increase global warming. BMJ Clin. Res. Ed. 2015, 351, h3738. [CrossRef] 
34. Rodriguez, D.; Valari, M.; Payan, S.; Eymard, L. On the spatial representativeness of NOX and PM10 monitoring-sites in Paris, France. Atmos. Environ. X 2019, 1, 100010. [CrossRef]

35. Martin, F.; Santiago, J.; Kracht, O.; García, L.; Gerboles, M. JRC Technical Report-FAIRMODE Spatial Representativeness Feasibility Study; European Commission-Joint Research Centre Institute for Environment and Sustainability: Ispra, Italy, 2015. 